Ghana: science hangs on amid economic chaos

\section{By Joseph Hanlon}

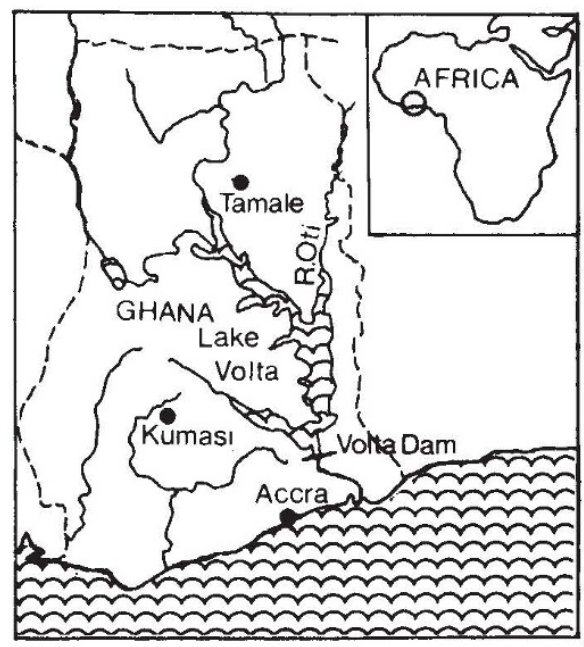

\section{Research fails to}

THE Council for Scientific and Industrial Research (CSIR) "has not been able to make the desired impact on the Ghanaian economy" and should be radically restructured, concluded a committee to review CSIR which reported in February 1977. CSIR is Ghana's largest science body. It controls nine research institutes and has an annual budget of 21 million cedis ( $£ 3.85$ million). It was set up in 1968 following the recommendation of a committee of experts chaired by Sir John Cockcroft.

The 1977 committee was headed by Dr Edward Ayensu, a Ghanaian who is director of the endangered species p-ogramme at the Smithsonian Institution in Washington, DC. The 0 her two members were Professor Alastair M. North, vice-principal of the University of Strathclyde, and Dr W. Gerald Matlock of the University of Arizona.

They praised some CSIR units, such as the Building and Road Research Institute, which maintains "balance and relevance". But they found that "the research programmes of many of the CSIR institutes can only be described as an amalgamation of too many unrelated, academically oriented, poorly defined projects. Well written objectives and a realistic time scale are lacking. No attempt has been made to establish priorities and relate projects to country needs. Little co-ordination of the effort has been provided by CSIR and the
Ghana is a small country of 10 million people on the Gulf of Guinea in West Africa. The former Gold Coast, it became independent in 1957 under Kwame Nkrumah. He inherited a colonial economic pattern with its emphasis on the export of primary raw materials. Today, cocoa is still Ghana's largest export, followed by timber, gold, and diamonds.

Nkrumah's government and all succeeding ones have been committed to economic independence. There has been considerable industrialisation and the Volta Dam now supplies much of Ghana's electricity. But Ghana has become even more tied to the world economy.

The military has dominated the government throughout much of the past decade. It overthrew Nkrumah in February 1966. A civilian government was elected in 1969 , but overthrown by the military in January 1972. That military government was marked by a spectacular degree of corruption and mismanagement. More than $£ 100$ million has been smuggled out of the country by government and commodity marketing board officials.
To meet its commitments, the government simply printed moneysince 1972, the money supply has gone up at a steady $80 \%$ a year, leading to massive inflation.

Two years ago, students and professionals began a long series of protests, eventually leading to the resignation of General Ignatius Acheampong as head of state in July 1978. A constitutional assembly was set up to lead to civilian government. Political parties were established in January and elections are scheduled for June.

One year afiter independence Nkrumah's government set up a National Research Council. Ghana also has three universities, with active scientific research at two: the University of Science and Technology at Kumasi and the University of Ghana at Legon, just outside Accra. Local institutions produced 4,234 graduates and diplomates in science and technology between 1951 and 1974. Applied research is under the guidance of the Council for Scientific and Industrial Research in Accra, which has nine research institutes under it.

\title{
make a real impact
}

fragmented nature of the research increases the costs of both equipment and facilities. New projects continue to be proposed and implemented but the completion rate of the projects is near zero."

Its collective ego badly bruised, CSIR set up a committee headed by its chairman, Professor Albert N. Tackie, to issue a response later that year. Most of Ayensu's objections were simply swept aside. But Ayensu has made his point and fundamental changes have made CSIR more mission oriented.

The Food Research Institute was the target of some of Ayensu's most bitter attacks. Research officers returning from study abroad simply continued their own projects, he said. No one worked together and no one looked at the needs of Ghana. The result was an "undue proliferation of openended research projects which are either beyond the capacity of the staff or else are too fragmentary to make an effective impact."

At the Food Research Institute, a new head, J. Maud Kordylas (appointed just before the Ayensu visit), has scrapped almost all previous research projects. Scientists now work in one of four groups: food storage, labour saving rural technology, processing, and consumption. No one works alone; scientists must pick one of the four teams to work with, independent of past training. The storage team actually goes to villages to collect samples and analyse for moisiure, insects, mould, aflatoxins, etc. Traditional fish processing, both smoking and drying, is now being studied. With FAO help, the institute is trying to design an improved smoker with less wastage. The multidisciplinary team includes an engineer looking at smoking units, a biochemist checking the bioavailability of protein with rat experiments (charring reduces protein availability), and so on.

The Industrial Research Institute also came under attack by Ayensu and it, too, is being substantially restructured. Dr M. N. B. Ayiku, the Institute's head, explained that in the past "we had lofty ideas -finding new raw materials and developing new processes. Now we realise the important thing is for industry to survive. And we realise that for industry to grow, we must have many small industries."

Some changes have not been made, however. CSIR suffers from an only-the-best-is-good-enough syndrome. It still budgets for large amounts of foreign exchange it knows it will not get.

Nevertheless, there is a new enthusiasm at CSIR that, despite administrative and economic problems, the scientists could work togther toward the solution of the country's problems. They admit they are just starting. But as Ayiku noted: "If we had concentrated on small industry 10 years ago, by now we would have made a significant contribution." $\square$ 